\title{
Latour a sémiotika: Teorie znaku jako součást a kritika ANT
}

\author{
Latour and Semiotics: The Doctrine of Signs \\ as a Part and Criticism of ANT
}

Martin Švantner

\begin{abstract}
The study's focus is to identify the conceptual conditions of Latourian ANT as conditions that can be formulated as a specific theory of sign (so-called "material-semiotics"). Therefore, the main aim of the paper is to analyse selected semiotic aspects of the Actor-Network Theory (ANT), namely Latour's definition of an "actor" as an "actant" and his notion of the "semiotic fabrication" of agency. The interpretation strategy of this essay is a critical comparison of different understandings of the theory of the sign, namely (Saussurean) semiology, (Greimasian) semiotics and (Peircean) semeiotic. Interpretations of these semiotic paradigms comprise the main part of the text along with the evaluation of the Kohn-Latour debate, which can be understood as a more specific development of the Peircean semeiotic. The study points out the controversial aspects of Latour's acceptance of certain semiotic concepts and their subsequent transposition into the ANT area.
\end{abstract}

KEYWORDS Latour, Peirce, Greimas, Kohn, semiotics, agency

\section{Sémiotická fabrikace aktérství?}

Vědecká civilizace okcidentu prrišla se třemi základními ontologickými prŕstupy, kterými se snaží popsat obecný rozměr souboru působností (agency), který lze nazvat jako ,jednání“ anebo „aktérstvi““ (Latour 1996, s. 369). První dva zdroje aktérství jsou již od sofistů (Gagarin 2002, s. 65-72) spojeny s ohledem na postulát souběžnosti, protichůdnosti a komplementarity (i) řádu přírody (a přirozeného) a (ii) řádu kultury (sociálně fabrikovaného). Cílem tohoto textu není pojednávat o této pradávné Ústavě a její „očišt'ující síle“ (Kobes 2015: 303; Latour 1993). Tématem tohoto textu je (iii) třetí perspektiva, sémiotické fabrikace, ${ }^{1}$ která chápe

Sociální studia / Social Studies 2/2020. S. 13-32. ISSN 1214-813X.

1 „Sémiotikou“ zde rozumíme teorii znaku a obecně teorii znakových soustav a systémů, která vzešla z širokých diskusí mezi lingvistikou, antropologií, filozofií a literární vědou. Součástí této teoretické rodiny je i strukturální sémantika J. A. Greimase. „Sémiologií“ míníme teorii znaku ve velkém svázanou s odkazem Kursu obecné lingvistiky F. de Saussura (CLG). „Sémeiotikou“ míníme teorii znaku popisující „sémiosis“ (proces vzniku a akce znaků), jak je spjatá s východisky C. S. Peirce. Peircova sémeiotika není součástí sémiologie ani (v uvedeném smyslu) sémiotiky. V českém prostředí (a nejen v něm) dochází $\mathrm{k}$ celé řadě omylů díky nedůslednému odlišení různých tradic a př́stupů, sémiotika je často považována za něco unifikovaného, a priori spojeného s naivní formou reprezentacionalismu (srov. Švantner 2014, 2017). 
dva zmíněné póly (natura contra cultura) jako „sémioticky konstruované“ a která chápe aktérství jako v základu svázané s „vytvářením významu“ (Latour 1996: 369; Latour 2014b: 2). Latourem je toto prizma (iii) prezentováno jako bytostně jazykově- / textově- / diskurzivněcentrické a de facto i de iure tak svázané se sémiotickou teoriii. ${ }^{2}$ Rafinovanost třetího pohledu spočívá v pochopení - jak domněle „„̌istě“ přírodních, tak domněle „čistě“ sociálních - zdrojů aktérství jako dynamických významotvorných procesů, a nikoliv jako generativních a determinujících substancí.

Avšak i sémiotická fabrikace upadá do pasti logocentrismu, kterou je asymetrická redukce aktérství na lidský jazyk, absolutizovaný jako primární modelující systém (Lotman 1991, srov. CLG, s. 34; Hjelmslev 2016, s. 141), chápaný jako jediný zdroj utváření významu, skrze který a fortiori něčemu jako „príroda“ a „kultura“ vůbec rozumíme. Latour et cie (Law 2008) jako jisté východisko z této logocentrické pasti proponují př́stup nazvaný jako „materiální sémiotika“ či „sémiotika věcí“, který nemá za cíl výdobytky strukturální teorie znaku zcela zavrhnout, ale spíše dosah jejích modelů rozšířit i mimo její tradiční domény - na oblast mimojazykových (a tedy non-lidských) věcí.

Pokud je tedy aktérství rozuměno jako procesu, kdy se ona působnost překládá skrze pohyb mezi aktanty a aktéry (Latour 2014b), jejichž určující vlastností je něco nějakým způsobem reprezentovat, jinými slovy zastupovat něco jiného, než jsou aktéři sami, dostáváme se na pole otázky, co je to ono, skrze co se zprostředkovává, ergo na pole teorie znaku (Hostaker 2005, s. 5). Sémiotika, sémiologie a sémeiotika (Švantner a Šedivcová 2019) pak jsou z definice a názvu disciplíny, v jejichž základu stojí analýza tohoto specificky vztahového zprostředkovávajícího jsoucna, bytostně spjatého s pojednáváním o významu, kterým je znak. ${ }^{3}$

Snahou tohoto textu je ukázat, že Latourovo metodologické odsunutí obecné teorie znaku pouze do narativu obecně sémiologického a př́ípadně post/strukturalistického ,panlingvismu“ je samo jistým redukcionismem a „očištováním“ teorie znaku o její podstatnou součást, kterou je tradice vzešlá $\mathrm{z}$ díla $\mathrm{C}$. S. Peirce. ${ }^{4}$ Tato redukce obecné teorie znaku není jen věcí daného teoretického a metodologického žargonu či arbitrárně zvoleného, „lehkonohého“

2 Jmenovitě se Strukturální sémantikou J. A. Greimase (1996). Latour se Greimasových seminářù přímo (společně s P. Fabrim a F. Bastidovou) účastnil - viz Latour a Weiss (2009); Latour (1996b: 243); Latour (1979: 91; 185); Latour (1988: 35); Latour (1993: 63); Latour (2005: 54; 126); Latour (2006: 79); srov. Harman (2009: 13); Hostaker (2005; 2014: 138).

3 Latour charakterizuje ANT jako, ,napůl Greimas a napůl Garfinkel“ (2005, pozn. 54). Tento text kriticky navazuje na studie R. Schleifera (2009), viz zejm. kapitola 4; R. Hostakera (2005); J. Beetze (2013; 2015); T. Lenoira (1994) a K. McGee (2014). Na komplementaritu Latourovy výbušné rétoriky a smyslu pro detail ukazuje Konopásek (2015).

4 Která není de facto „výsledkem zkřížení literární vědy a strukturální lingvistiky“ (Eagleton 2010: 125) a která má hlubší historické kořeny, mj. v pojednáních scholastického a postscholastického realismu, který, hrubě řečeno, pojednává o obecné teorii relací a multiplikaci těchto relací mezi kognitivní mohutností organismů a na mysli závislých a nezávislých objektů. Srov. Bains (2006); Deely $(2001 ; 2009)$; Hanke et al. (2015). Důležité je poznamenat, že tato perspektiva se nijak neváže na novověký dualismus, který přetrvává do velké míry i v moderním francouzském teoretickém myšlení, který se Latour z pochopitelných (lingvistickocentrických) důvodů snaží opustit. 
(Konopásek 2015, s. 123) slovníku, ale má také závazné ontologické a ontonomické (Latour 2014b) předpoklady a důsledky.

Debatu o sémioticko-ontologických aspektech teorie aktér-sít' (dále ANT) tedy lze vést mimo rámec Latourova obecného dělení na „sémiotiku diskurzu“ a výše zmíněnou „,sémiotiku věcí / materiální sémiotiku“ (Latour 1996, s. 375; Law 2008), kde právě „,sémiotika věcí“ by měla být kontrapoziční, či minimálně doplňující, vzhledem k diskurzivněcentrickému pojetí aktérství. Tato perspektiva (vulgárně vyjádřeno: „diskurz vs. věci“) může být nahlížena $\mathrm{v}$ rámci diskuse o realistické a nominalistické povaze znaku jakožto specifické relace: míníme „znakem“ fenomén, který je konstruovaný výhradně mohutností lidské mysli, nebo míníme ontologicky svébytnou relaci, která není na lidský jazyk redukovatelná?

Tuto debatu nelze shrnout jednoduše tak, jak to činí T. Lenoir (1994, s. 126), když říká, že Latour je nakonec archaickým realistou hledajícím znaky ve věcech o sobě. Není nic vzdálenější jeho perspektivě. Latour je často napadán z protichůdných pozic: pro tradiční obhájce moderní vědy je dalším francouzským relativistou popírajícím skutečnost vnějšího světa a např. pro následovníky P. Bourdieua je Latourovo zacházení s non-lidskými aktéry výrazem právě „fosilního realismu“ (Harman 2009, s. 5). Tento text se nesnaží Latoura zařadit do nějaké rubriky, ale rozvinout podnět, na který poukazuje v recenzi Harmanovy (2009) knihy J. Hartmann (2010, s. 69), když říká, že v Harmanově a Latourově korpusu neexistuje pojednání o Peircově pragmaticismu, dodejme, že stejně tak - až na níže tematizovanou výjimku Latourova dialogu s E. Kohnem - neexistuje ucelené pojednání o peircovské či postpeircovské teorii znaku.

Cílem tohoto textu je ukázat, jakým způsobem tyto slovníkové limitace spojené právě s francouzskou tradicí teorie znaku determinují vybudovaní silnější teoretické, sémioticko-ontologické perspektivy vztažené k teorii aktéra-sítě. Limity jsou v tomto směru navázány na: (i) Latourův metodologický nacionalismus (tedy preferování při výkladu znakové teorie sémiologických modelů a strukturální sémantiky J. A. Greimase ${ }^{5}$; (ii) simplifikující (či spíše naprosto marginální) čtení Peircem ovlivněné sémiotické tradice; (iii) nerozlišování mezi základními (sémiologickými a sémeiotickými) paradigmaty, které implikuje nemožnost přesnějšího uchopení znaku specifické ontologické relace, jež transcenduje „sémiotiku jazyka“ a ,sémiotiku věcí“, aniž by upadalo do pasti lingvistického absolutismu, technického scientismu nebo hrubého naturalismu.

Po vlastní analýze této teoretické problematiky níže ilustrujeme její vybrané aspekty právě na proběhlé debatě mezi Latourem a E. Kohnem. Zatímco Kohn (2013) reprezentuje přístup biosémiotický, Latour zůstává, co do slovníku a některých ontologických aspektů jeho teorie, na strukturálně-sémiotických pozicích (Latour 2014). Závěrečné části textu se tak snaží načrtnout rozdílné důsledky plynoucí z různého přístupu $\mathrm{k}$ sémioticky fabrikovanému aktérství.

Text, ač je polemický a kritický, je psaný v úctě a lásce $\mathrm{k}$ mimořádně podnětnému dílu Latourovu. Jelikož, řečeno s R. Barthesem, ,člověk vždycky selže, když píše o tom, co má rád“،, i tento text evidentně selhává ve smyslu toho, že nutně ignoruje významnou část Latourova rozsáhlého díla.

Srov. vymezení Latourova vztahu ANT k sémiotickým teoriím (vedle Greimase také k Ecovi a Hjelmslevovi) in McGee (2014); Beetz (2013, 2016). 


\section{Sémiologie, sémiotika a sémeiotika: znak jako vztah?}

„Znaku“ lze předběžně rozumět jakožto formě relace, ${ }^{6}$ která specifickým způsobem spojuje určité, definované a navzájem odlišené prvky. Co jsou však tyto prvky, jaká je povaha této relace a jak jsou tyto elementární termíny strukturálně usouvztažněny?

Klíčovou otázkou tohoto textu tedy je (i) jak vůbec Latour samotné teorii znaku (znaku jako relaci a pojmu „znaku“) rozumí; (ii) jakým způsobem tyto koncepty v rámci ANT používá a (iii) jaké dopady má jeho pojetí teorie znaku pro jeho obecnou epistemologickou perspektivu. Cílem je ukázat, co Latour přesněji míní, když používá termíny jako „sémiotický“ a „sémioticky konstruovaný/fabrikovaný“, a rozebrat teoretické, paradigmatické a významové limitace použití těchto klíčových pojmů.

Pokud chceme hlouběji porozumět „sémiotice věci““ svázané s ANT, kterou někteří Latourovi následovníci chápou jako nový (či pragmatický) realismus (Salinas 2014), jako ontologický obrat v antropologii a etnografii (Kelly 2014), či jako relacionistický obrat v sociologii (Papilloud 2018; Archer 1995), je tak třeba prvně:

i) rámcově porozumět (strukturálně-lingvistické) diskurzivněcentrické sémiologii (a z ní vzešlé strukturální sémantice alias sémiotice, která tvoří základní osu Latourových úvah o vztahu aktant-aktér) a v kontrapozici stojící (logicistně, inferencialisticky, naturalizující) Peircově sémiotice. Toto implikuje nutnost porozumění fundamentálně odlišným ontologickým předpokladům, zejména pokud jde o vypracování pojmu „znaku“ (a s ním pak spojený obecný termín „významu“);

ii) vysvětlit teoretický status pojmu „,vztahu“, „věci“ a „objektu“ v rámci těchto paradigmat.

Uvažování toho, co je znak, jakožto element obecného procesu signifikace a elementární jednotka utváŕení významu, dospívá ke dvojznačnému závěru. Znak je relace, avšak jako taková může být nahlížena ze dvou ontologicky fundamentálně odlišných perspektiv?:

i) perspektivy strukturálně-lingvistické, ergo sémiologické, kde znaku je rozuměno jako dyadické diferenčně-systémové relaci odvozené od hlubinné povahy strukturálně-diferenčního ustrojení lidského jazyka;

ii) inferencionalisticky-logicistní ergo sémeiotické, kde znak je triadická ontologická relace, která není redukovatelná pouze na jazyk.

6 K podrobnější analýze znakové relace ve vztahu k jiným typům relace viz zejm. (Bains 2000; Meier-Oeser 1997; Deely 2001), k otázce povahy znaku jako relace viz (Short 2007; Švantner 2014; Švantner 2017; Švantner a Šedivcová 2019).

7 Přestože je tento fakt v oboru dějin obecné sémiotiky považovaný za již vyřešenou věc, můžeme se setkat $-\mathrm{v}$ českém prostředí běžně - $\mathrm{s}$ celou řadou omylů, přičemž lze $\mathrm{s}$ jistou rezervou říci, že zdrojem těchto omylů jsou práce R. Jakobsona, U. Eca a J. Derridy; srov. Lotman (2003); Gvoždiak (2018; 2016, s. 40-45); Švantner a Šedivcová (2019); Švantner (2014); Švantner (2017). 


\section{Sémiologie a strukturální sémantika: od jazykového systému přes strukturální sémantiku $k$ aktanční síti}

\section{Sémiologie a strukturalismus}

První perspektiva (i) je tradičně svázána s dědictvím Saussurovy strukturální lingvistiky a Hjelmslevovy glosematiky, které se staly bezmála kanonickou součástí francouzské sémiologie a strukturalismu. Perspektiva je spojena s predominantním analytickým postulátem uchopení lidské schopnosti řeči (langage) ve dvou dimenzích možné analýzy jako: jazyka (langue), obecného systému později nazývaného jako struktura; a mluvy (parole), empirických variací této struktury (CLG, s. 31-32). Veškeré zkoumané entity tak lze chápat jako vykazující stejný vzorec strukturálních vlastností (Gvoždiak 2014a, s. 91), modelovaných podle obecných vztahů daných jazykem, který lze přirovnat k symfonii, ,jejíž realita je nezávislá na způsobu provedení“ (CLG: 36). Tento jazyk-systém není konkrétním přirozeným jazykem, ale je, jakožto čistá forma, podmínkou jakéhokoliv přirozeného jazyka a jeho pravidel. ${ }^{8}$ Jak uzavírá Gvoždiak, ,[i]dentifikace a opozice jsou tak základními principy organizace znakové struktury, kterou lze považovat za univerzální napříč nejrůznějšími př́istupy“ (Gvoždiak 2014b: 41). Obecný jazyk (langue) pak nemá žádnou přirozenou ani striktně sociální generativní substanci. ${ }^{9}$ Odtud lze sledovat jak Latourovy sympatie (jazyk uchopený jakožto „střední pole“ mezi př́rodou a kulturou), tak kritiku a nedůvěřivost vůči strukturalistickému panlingvismu, který marginalizuje svrchovanost aktérova jednání. Pro Latoura je jazyk autonomní pouze do jisté míry - texty se nepíší samy a diskurzy se samy nerozprávějí.

Elementem jazyka, formálně-vztahové entity, je bazální diferenční relace, tj. znak (Eco 1984, s. 23). V rámci obecně lingvistického a sémiologického prizmatu je znak interpretovaný jako mentální jednotka spojující ideu formy samotné (označující) a ideu významu této formy (označované), která se „vymyká [...] vůli společnosti a jednotlivce“ (CLG: 34). Hodnota (a identita) znaku jako elementu struktury je, co do jejího základního určení, diferenčně relační (znak je definován tím, co není) a arbitrární (esenciální vztah jednoty označujícího a označovaného je nemotivovaný ve smyslu toho, že nic z označujícího nutně nedeterminuje označované a vice versa). Nejdůležitější je si uvědomit, „že akustický obraz se se zvukem samým neshoduje a že je psychický jako pojem, který je k němu asociován“ (CLG: 29, srov. CLG, s. 97-100). Na této koncepci znaku tak není v důsledku nic „materiálního“.

\footnotetext{
A tedy je nutnou podmínkou utváření jakéhokoliv významu.

Jazyk nelze vysvětlit pouze naturalisticky (konkrétní fonace jsou jeho projevem) ani sociálně-deterministicky. Ačkoliv Saussure vágně hovoří o sociální psychologii a jazykové komunitě, dle mého soudu se tyto poznámky spíše vztahují k tomu, jak se obecný jazyk realizuje jako systém užívaných pravidel, nikoliv k tomu, jak je co do své obecné a abstraktní formy určen. Navíc, jak připomíná význačný badatel v této oblasti R. Engler (2004, s. 52), nebezpečí dezinterpretace Saussura spočívá právě v tom, že jeho žák (a spolueditor CLG) Albert Sechehaye přisoudil Saussureovi „,ideu integrující lingvistiky (a částečně jazyka) spadající do oblasti sociální psychologie [...], která je sama integrována do individuální psychologie. [P]řičemž Saussure tento problém řešil [...] skrze odlišné perspektivy různých sociálních věd.“ Pokud má R. Engler pravdu, jedna z nejvlivnějších myšlenek, která stála za zrodem strukturalismu, je tak vlastně editorskou invencí.
} 
Saussure pak rozpracovává dále možnost toho, jakými zpo̊soby jsou vztahy mezi elementy obecného systému jazyka ustrojeny. Povaha těchto vztahů může být viděna syntagmaticky, tedy koexistenčně-rozsahově, tj. lineárně a ve vztahu k prŕitomným prvkům; a paradigmaticky, tedy ve vztahu k nepřítomnému, tedy ,asociačně“.${ }^{10}$ Přeneseme-li tyto postuláty ${ }^{11}$ do širšího kontextu dalších forem vytváření významu, dostáváme se k tomu, proč se sémiologie, jakožto „věda, která studuje život znaků ve společnosti““ (CLG: 33), stala obecným modelem pro výzkum v různorodých sociálněvědních oborech a základem pro uvažování o aktérství. ${ }^{12}$ Sociálně-kulturní aktérství lze více či méně odvodit z pravidel, která mají svůj předobraz v tomto smyslu „,idealistickém“ pojetí reality jazyka (langue). Aktérství je zde spojeno s utvářením významu ve smyslu toho, že neexistuje mimo sít’ diferenčně (syntagmaticky a paradigmaticky) definovaných vztahů, ergo mimo sít’ dyadických znaků/relací. Sémiologický př́stup obsahuje řadu ontologických problémů, které se staly později námětem obsáhlých diskusí, zejména pak problém opomenutí hlubší analýzy dalších možných forem funkčních vztahů uvnitř jazykového (a sociálního) systému (srov. Hjelmslev 2016, s. 175-183). ${ }^{13}$

Stejně jako bylo třeba se omezit na několik základních témat ohledně sémiologického uchopení znaku, omezíme se i dále na rámcový výklad klíčových událostí, které byly podstatné pro vypracování Latourovy perspektivy. ${ }^{14}$

Pro argumentaci tohoto textu je podstatné následující terminologické vymezení. Historicky, mezi prací Saussura, Hjelmsleva a Greimase, se zavádí do frankofonního paradigmatu znakové teorie termín ,sémiotika“, který však hraje několikerou úlohu. Bud' se používá jako synonymum pro sémiologii a znamená tedy obecnou teorii znaku, avšak stále vázanou na saussurovské (jazykověcentrické) dědictví, nebo se ztotožňuje se samotným procesem fungování a vytváření znaků, nebo se dokonce překrývá s pojmem ,,jazyka“ či ,jazykového úzu“ (Hjelmslev 2016, s. 140). Podstatné zde je, že žádný z těchto obsahů tohoto výrazu (,sémiotika“), jak uvidíme v druhé podkapitole, se nepřekrývá s tím, jak s ním pracuje peircovská tradice, která se - rozhodně ne pouze - odlišuje tím, že zavádí př́ísné rozdělení mezi samotnou akcí a vznikáním znaků (sémiosis) a teoretickou doktrínou, která ji studuje (sémeiotikou).

10 Uvedené lze ilustrovat na př́kladu číslovky - z asociativního (paradigmatického) hlediska je výraz „dix-neuf“ (devatenáct) motivován svými vztahy k výrazům jako „dix-huit“ (osmnáct) nebo „soixante-dix“ (sedmdesát). Ze syntagmatického hlediska je motivován svými složkami „dix“ a „neuf"; podle Gvoždiak (2019).

11 Založené v konceptu jazyka jakožto systému znaků, který vyjadřuje ideje (CLG: 33) a který význam těchto idejí může vyjadřovat pouze díky tomu, že existuje jako čistá forma obsahující pouze diference (CLG: 166).

12 Např. u relacionistické sociologie P. Bourdieua (1998), srov. Schinkel a Tacq (2004).

13 Jako je např. u paradigmatických vztahů komplementarita, autonomie a specifikace; u syntagmatických vztahů solidarita, kombinace a selekce atp. Tato intence je zřetelná již u Hjelmsleva, na kterého v tomto navazuje M. Haliday, viz Bache (2010).

14 Pro účely tohoto textu zde vynecháme podrobný rozbor Hjelmslevovy nauky reinterpretující základní témata CLG, která měla podstatný vliv na Greimasovu teorii. Srov. Ablali (2001); srov. Hjelmslevovo deduktivně-algebraické pojetí znakové funkce jako solidarity mezi výrazem a obsahem. Viz dále Clarke (1981: 117-145); Pettit (1977). 


\section{Strukturální sémantika}

Greimasova strukturálně-sémantická perspektiva sdílí se sémiologií základní komponentně-analytický předpoklad toho, že širri empirické variace lze systematicky redukovat na omezený počet elementů či funkcí (srov. Eco 1984, s. 190-191). ${ }^{15}$ Oproti saussurovskému prizmatu je však jejím základem nikoliv primárně obecný, synchronní systém jazyka (langue), ale obecná sémantika řeči (langage), která propojuje jak jazyk jakožto paradigmatický a korelační systém (langue), tak mluvu (parole) jakožto syntagmatický relační proces (Schleifer 1988, s. 85). Úkolem badatele tak již není pouze kvaziplatónská redukce empirických variací na supersystémové aspekty, ale výzkum toho, co jsou to základní prvky, které mohou nést nějaký význam, jakým způsobem se tyto prvky spojují v nějakých výpovědích a jak pracují tyto výpovědi v širším, narativním kontextu (Greimas a Courtés 1982, s. 278-279; Greimas 1983, s. 50-55; Eco 1984, s. 99).

Greimasova sémiotika, následujíc v tomto Hjelmsleva (2016, s. 65-72; Greimas 1966, s. 5-17), je pokusem analyzovat pravidla, za jakých se utváríi význam nejen v př́padě jednotlivého znaku, ale i v rámci širších významotvorných bloků jako jsou věty, texty či diskurzy. ${ }^{16}$ Podobně jako Hjelmslev (2016, s. 65-73) i Greimas se snaží nejprve izolovat nejmenší možné jednotky, ze kterých se skládají vyšší významotvorné celky: „atomy“ signifikace (Eco 1984, s. 22), jejichž prostřednictvím „neustále nového uspořádávání může konstruovat celé armády znakü“ (Hjelmslev 2016: 72). ${ }^{17}$ Podstatným aspektem, který hraje důležitou úlohu i v Latourově myšlení, je, že tyto základní jednotky tvoří sít' základních korelačních významotvorných vztahů, tedy vytvárí narativní sítě, kde narativitě je rozuměno jako syntaktické formě organizace světa (Greimas 1989, s. 543).

Greimas chápe jako minimální jednotku jakéhokoliv významu binární elementární strukturu (tzv. sémickou kategorii) konstituovanou minimálními jednotkami, tzv. sémy. Jde o dva základní distinktivní rysy, které lze interpretovat jako opozici privativní a ekvipolentní (Filipec 1969, s. 424). V prvním, „příznakovém“, privativním př́ípadě jde o vztah, kdy sémantický prvek, který je u jednoho členu př́tomný u druhého absentuje (např. dvojice velký-malý), přičemž u druhého ekvipolentního, „bezpříznakového“ typu binárního vztahu, kde opozice je rozeznána, pokud sém jednoho členu je u druhého členu nejen nepř́tomný, ale je nahrazen jiným: např. „lexém hoch se sémem ,mužskost‘ je vztahu r (,pohlaví) s lexémem dívka, u něhož je sém ,ženskost'. Tyto dva základní typy binárních opozic [...] doplňuje [Greimas] variantami, kdy krajní členy privativní opozice doplňují prostřední člen bud' neutrální, nebo komplexní“ (Filipec 1969: 424). Z tohoto základního určení pak

15 Lenoir (1994) hovoří o Greimasově generativní gramatice narativu či textu, toto prrirovnání je však vzhledem k zcela odlišným ontologickým, metodologickým východiskům (Greimase a Chomskyho) zavádějící (srov. Greimas 1971, s. 794).

16 V intencích Hjelmslevových (2016, s. 145) i Greimas (1987, s. 63) chápe sémiologii jako podřízenou obecné lingvistice.

17 Tyto jednotky jsou pak nazvány jako sémy (základní definiční znaky), lexémy (hierarchizace těchto definičních znaků) a klasémy (kontextuálně-selekční vlastnosti sémů, jak je navrhuje interpretovat Eco (1984, s. 106); srov. Greimas (1966, s. 46-47). Jelikož tento aspekt netvoří výslovnou součást Latourovy perspektivy, dále se mu nevěnujeme, více viz Filipec (1969); Gregorczyk (1989, s. 57-58); Dorfman (1969). 
(zjednodušeně řečeno) Greimas definuje základní „konceptuální sít““ (Herbert 2007), která je složena z elementárních binárních vztahů. Sít' generuje jak komplexnější vztahy kontrárnosti, kontradikce a komplementarity nebo implikace a v dalším plánu vůbec možnosti komunikační deixe. Ačkoliv Latour pro své vlastní záměry ohledně sémiotiky vychází převážně z Greimasovy teorie, k jádru samotné teorie (tzv. sémiotickému čtverci) se nevyjadřuje, a jak si všímá J. Beetz (2013, s. 8), nikde k této koncepci neodkazuje. Latour si tak z Greimasovy sémiotiky odnáší vedle obecného programu akcentující možnost „skutečné“ analyzovat jako „textové“, především citlivost k různorodě artikulovaným diferenčním vztahům.

Tedy i Greimas (1966, s. 18-29) sleduje analogickou logiku znaku jako systémově-diferenční relace (srov. Murphy 1991; Deely 2010, s. 26-27). Tato perspektiva vidí význam jakéhokoliv objektu jako utvořený v rámci hierarchizované struktury vztahů a sémiotika (chápaná $\mathrm{v}$ této posthjelmslevovské perspektivě konfúzně/podvojně jako teorie znaku i jako samotný znakový proces) tak stále zůstává jazyku analogickou, racionalisticky-deduktivistickou doktrínou, která je hierarchií ,[...] z jejíchž komponentů lze libovolný komponent dále dělit na trrídy definované vzájemnou relací tak, že libovolnou z těchto tříd lze dělit na deriváty definované vzájemnou mutací“ (Hjelmslev 2016: 140).

Greimas se tak zcela nezbavuje základního aspektu strukturalistického programu: význam znaku či komplexnější narativní struktury je stále pochopený striktně jako věc diferenční relace, která, i přes svou provedenou subtilnější klasifikaci, je věrná diferenčně-binaristické metodě dělení (na označující a označované, substanci a formu, výraz a obsah, jazyk a nejazyk, vysílače a príijemce... hrdinu a padoucha).

Stejně tak je tomu i u klíčového pojmu „aktant“, který Latour přebírá od Greimase. Aktant (tedy bytí něčeho, co vykonává nebo podstupuje nějaký akt) je Greimasem a Courtésem $(1982$, s. 5) formálně definovaný jako typ syntaktické jednotky, která předchází nějaký sémantický anebo ideologický obsah a která usouvztažňuje elementární funkce výpovědi. ${ }^{18}$ Pro Latoura je klíčové rozlišení mezi aktantem jakožto součásti syntaxe většího, obecného, významotvorného celku (narativní syntax) a aktérem, který je konkrétní, diskurzivní manifestací této struktury (Greimas 1987, s. 106) ${ }^{19}$ Druhým podstatným aspektem je fakt, že aktanty-aktéri mohou být povahy jak lidské či antropomorfní (Frodo), non-lidské (prsten), tak konkrétní (dýmka) či abstraktní (svoboda). Proto se hovoří o „strukturální sémantice“ význam aktérství je obecně dán jak strukturální pozicí daných aktérů (tj. syntagmaticky ve vztahu ke svému okolí: tedy vztahem k ostatním manifestovaným prvkům narativní syntaxe), tak možností jejich specifické aktanční transformace (tj. paradigmaticky, ve vztahu ke všem realizovatelným možnostem vyplývajících z jejich vztahů a kontextu). Aktanční strukturu je tak možné interpretovat jako monadický systém (Harman 2009, s. 14) základních vztahů

18 A to $\mathrm{z}$ různých hledisek typologicky vztažených $\mathrm{k}$ danému diskurzu vypovídání. Lze tak hovořit o komunikační struktuře aktantů (klasifikovaných podle strukturálních pozic vypovídajících, např̀. v dialogu apod.), narativní aktanční struktuře (subjekt/objekt výpovědi, vysílač/př́ijemce, oponent, pomocník); z perspektivy gramatické aktanční struktury (předmět stavu, předmět jednání).

19 Jak uvádí Beetz (2013: 7), ,[z]jednodušeně můžeme říci, že aktéři jsou věci, které mají v daném narativu jména [...], a aktanty jsou narativní jednotky, které manifestují. Jeden aktant se může manifestovat několika aktéry. Stejně tak obráceně, jeden aktér je schopen spojovat několik aktantů.“ 
(„,nebezpečí - úkol - test...“), které jsou dále agregovány (,,prsten moci - požadavek jeho zničení - cesta do Mordoru..."), přičemž význam a transformace těchto agregací je umožněn skrze hlubinnou strukturu jejich limitních stavů.

$\mathrm{Z}$ této perspektivy je tak povaha vztahu/znaku odvozena $\mathrm{z}$ diferenční logiky stále modelované podle primátu lidského jazyka. Stejně tak status věci i objektu je nakonec podř́izený pojmenování (které je nesené aktérem možné díky aktanční síti), a tedy a fortiori nominalistickému prizmatu (objekt je objektem, protože stojí v opozici k subjektu, tedy nemá žádnou bytnost o sobě). Řečeno s nadsázkou, strukturální syntaktika (jak ontologicky, tak konkrétně) má předcházet jak možnou sémantiku, tak pragmatiku.

\section{Latourova deteritorializace sémiotiky}

Latour ve své práci pochopitelně nepřejímá tento superracionalistický, univerzalistický, formalistický, primárně o deduktivní metodu opřený, stále primárně synchronistický, a tedy $\mathrm{v}$ důsledku redukcionistický top-down program, který evidentně koliduje s jeho symetrickou antropologii ${ }^{20}$ a jeho ohledem na empirické výzkumy. ${ }^{21}$ Latourovou snahou je strukturalistický racionalismus „zcizit“, či spíše deteritorializovat ${ }^{22}$ a akcentovat jeho podvojnou ontologii (vztahu aktantu a aktéra a jejich hybridních mísení). Encyklopedicky řečeno, Latour ve vztahu ke strukturalismu vystupuje jako revidující poststrukturalista. Pokud sémiotika nabízí analytické nástroje ke zkoumání obecné povahy textů jakožto narativů (Latour 2005, s. 55), je možné tak zkoumat i samotné vědecké texty jako typ sociální praxe. ${ }^{23}$ Analogicky i sémioticky fabrikované aktérství lze chápat jako narativ, tedy specificky/sémioticky/strukturálně sémanticky organizovanou činnost, jejíž zdroj se nachází v „artikulaci“, která není věcí pouze lidského jazyka, ale „ontologickou vlastností univerza“ (Latour 1999: 303). ANT je nakonec kvazigreimasovsky definována jako popis:

[a]tribuce lidských, ne-lidských [unhuman, inhuman], non-lidských charakteristik; distribuce náležitých vlastností [properties] mezi těmito entitami; stanovené spojitosti mezi těmito entitami; transformace těchto atribucí, distribucí a spojitostí jejich mnoha prvků a několika způsobů, jimiž jsou komunikovány [sent]. Přičemž obtíž pro uchopení ANT spočívá v tom, že byla vytvořena fúzí tří dosud nespojovaných koncepcí: sémiotické definice konstituce entit; metodologického rámce, který zaznamenává heterogenitu takové konstituce; ontologický nárok na sít’ový charakter samotných aktantů. (Latour 1996: 371)

20 K symetrii v rámci sociálních věd viz Brož a Stöckelová (2015).

21 Stejně tak Latour není kognitivista a hlubinná aktanční struktura vědomí je spíše stranou jeho zájmu (v tomto směru spíše následuje etnometodologii). Srov. Beetz (2013, s. 8), Brandt (2007).

22 Ke koncepci „deteritorializace“ srov. Charvát (2016, s. 84); k afinitám a rozdílům mezi teorií znaku mezi Peircem a Deleuzem srov. Charvát a Karl’a (2018).

23 Zde je zřejmé, proč je sémiotika „entometodologií textu.“ V této studii se nevěnujeme otázce „žánrovosti“ textů spojené s otázkou reference a zapojení (engagement/disengagement - shifting in/shifting out), kterou Latour také přebírá z Greimase a analogicky jiným jeho interpretacím ji rozšiřuje mimo její jazykověcentristickou doménu. 
Aktant je tedy cokoliv, co jedná nebo je s nějakým jednáním spojeno. Aktéra Latour reinterpretuje jako aktant nadaný nějakou (často antropomorfní) charakteristikou (Akrich a Latour 1992, s. 259), jehož zásadní vlastností je spojovat se (být ve vztahu) s jinými (aktančními) entitami (Harman 2009, s. 156). Aktér/aktantcentrická perspektiva se tak objevuje i v prípadě kdy (stále v intencích sémiotiky) Latour (1999, s. 303-304) redefinuje (a co do významu volně posunuje) dvojici paradigma-syntagma jako asociaci ${ }^{24}$-substituci: asociativní vazby vymezují možnosti spojení aktérů a substituční vazby se týkají okolností, za kterých může být jeden aktér nahrazen druhým. Latour často osciluje mezi pochopením vztahu aktant-aktér jak ve smyslu komplexní jednoty, tak ve smyslu saturace aktantu aktérem (kde aktant je uchopen jako „zatím nemanifestovaná figurace“ [Latour 2005: 71]), a někdy tyto termíny používá synonymicky. ${ }^{25}$

$\mathrm{K}$ posunu v definování aktantu-aktéra (a v podstatě $\mathrm{k}$ jasnému opuštění generativně-syntaktického charakteru Greimasovy sémiotiky ve prospěch pragmatiky) dochází v textu Pandora 's Hope (Latour 1999, s. 303), kde je akcent přenesený na možnost emergence a performance aktéra v rámci laboratorních testů (Beetz 2013, s. 9). ${ }^{26}$ Termín aktant pak má splňovat jednak rétorický (a také politický) důraz na non-lidskost aktérů. Poststrukturalistickým (a foucaultovským) rozměrem tohoto posunu je tak i Latourovo uchopení aktéra/aktantu jakožto něčeho, co klade odpor, tedy něčeho bytostně spojeného s mocí; a z tohoto vztahu vzešlých diskurzivních definic.

V Latourových očich, jak bylo naznačeno v úvodu, je chybou tradičních zdrojů pojetí aktérství asymetrické preferování vždy jednoho z pilírư: aktér je vždy - už ze své sémiotické konstituce - mísením. Chybou sémiotického pilíre je především obecně slepota $k$ utváření materializovaných aktančních sítí a k jejich vzájemné transformaci a př̀ekladu, která generuje z principu nikoliv „,̌isté“, ale „hybridni““ objekty. Deteritorializace sémiotiky jde tak dále, než je pouhá akcentace non-lidského v aktančním modelu a jistá komplexní procesualizace a dynamizace synchronistického strukturalismu. Hlavním cílem je sémiotiku materializovat.

24 Latour (2004) v knize Reassembling the Social „neodkazuje ke ,společnosti“ jako specifické (lidské) oblasti skutečnosti, ale k pojmu propojení - asociace“ (Brož a Stöckelová 2015: 13).

25 Nekonsistence používaného slovníku (či jeho „tvưrčího znovumodelování“) si všímá Beetz (2013, s. 9).

26 Latour však stále chápe „test“ (trial - épreuve) nikoliv mnohem šířeji - sémioticky a narativisticky. Vztah aktéra a aktantu je dramatem (Brandt 2007, s. 48). Např. ve smyslu toho, kdy mytický hrdina (aktér) podstupuje zkoušku (zdolání Hory osudu) za účelem osvobození (Středozemě) atp. Zkouška kvalifikace spočívá v tom, že dárce přikazuje nebo dává subjektu nějakou zkoušku a subjekt ji přijímá. Druhá zkouška je hlavní nebo základní či rozhodující, je to zkouška, kterou se vyřeší nedostatek nebo se získává to, co subjekt chce či musí. Poslední zkouška souvisí s tím, že hrdina úspěšně získává objekt nebo splní svou povinnost a jeho práce je uznána. Latour per analogiam chápe utváření objektů vědecké produkce neesencialisticky, tedy jako proces, ve kterém objekty procházejí těmito zkouškami (a také ,,akvizicemi kompetencí“) před tím, než jsou uznány jako aktanty. Latourův pragmatismus se pak odvijí právě od této myšlenky: performance předchází kompetenci, esenci objektu určuje výčet jeho zkoušek, srov. Latour (1999, sd 119). Beetz (2013, s. 12) se poněkud unáhluje, když jednoduše spojuje Saussurovu ideu označujícího s jeho poststrukturalistickou intepretací (spojení s mocí). 
Tedy re/deteritorializovat aspekty strukturalistické sémiotiky, která má, vzhledem k výše popsanému lingvistickému dědictví, tendenci chápat materiální jako závislé na nemateriálním (jako konkrétní fonace podléhá abstraktní organizaci langue). Latour chce ukázat jiné aspekty, než je redukce veškerenstva na několik základních funkcí - zatímco v Greimasově sémiotice redukce probíhá nesymetricky (v duchu sémiologie veškerou variabilitu empirického redukuje na veskrze deduktivně stanovené postuláty), Latour chce vysvětlovat zkoumané jevy symetricky: aktanční sít' není pouze věcí racionalisticky/formalisticky stanovených nemateriálních aktančních sítí, ale i materiálních vlastností „věcí samých“. Ačkoliv podle Greimase aktantem může být neantropomorfní entita, její aktérství je omezeno na abstraktní nemateriálno. V Latourově perspektivě však i non-lidské, empirické a materiální předměty konstituují aktanční (a tedy transformační - asociační a substituční) sítě. Triviálně řečeno, Pán Prstenů není pouze epický románový narativ, ale i fyzická kniha, lod' není pouze dopravním prostředkem, ale i nositelem kulturní směny a imperiální nadvlády, atp. Latourovými slovy, „[n]ový zájem o ,Pravdu' nepochází z nového zraku, ale z toho samého starého zraku, jenž se aplikuje na nové viditelné objekty, které jinak mobilizují čas a prostor“ (Latour 2008: 53).

Ilustrujícím prííladem je zde Latourova interpretace sémiotického termínu „inskripce“, obecného pojmu, který odkazuje „ke všem typům transformací, za kterých je entita materializována ve znak, archív, kus papíru, stopu“ (Latour 1999: 306-307). Tato reinterpretace ilustruje právě Latourovu snahu zavés ${ }^{27}$ do deduktivně-racionalistické sémiotiky materiální objekty. Avšak Latour tak nečiní za pomoci naivního materialismu spočívajícího v zapojení externího referentu („,ěci o sobě“), ale zavádí termín „cirkulující reference“, kdy jde o překlad umožněný různými aktančními sítěmi, který nezohledňuje pouze zapojení jejich syntakticko-narativních aspektů, ale i pragmaticko-materiálních. Jde tedy o transformaci věcí ve znaky a znaků ve věci, které, pokud v tomto procesu „utvoří silný řetězec“ (Beetz 2013: 26), „produkují cirkulující referenci“ (Latour 1999: 307).

Tento prríklad dále implikuje mnohem podstatnější věc a poukazuje na jistou teoreticko-metodologickou nerozhodnost vyvěrající z povahy Greimasovy sémiotiky. Na jedné straně je Latourem deteritorializovaná aktanční sémiotika něčím, co popisuje obecné vlastnosti entit (které jsou sémioticky utvářeny), a tvoří základ ANT (Latour 1996), na druhé straně, jak je patrné z výše uvedeného citátu, je znak jako takový chápan spiše jako něco konkrétně materializovaného. „Znak“ je tedy brán dvojsečně: jako inherentní součást konstituce zkoumané entity a jako konkrétní materializovaný znak: ,[m]ikroby, neutrina DNA jsou zároveň přirozené, sociální a diskurzivní. Jsou to také zároveň reálné, lidské sémiotické entity“ (Latour 1996: 339).

Analogickým problémem provázející sémiotické zakotvení ANT je tak nerozlišení mezi teoretickou disciplínou popisující to, co je „znak“, a samotným procesem vznikání a akce znaků. Toto rozlišení z deduktivistické perspektivy francouzského strukturalismu je bud' chápáno afinitně a transcendentálně, ${ }^{28}$ kde jazyk popisu je nakonec také znakový systém stejně jako jiný znakový systém, který popisuje; nebo je nahrazeno opozicí jazyka a mluvy, systému

27 Chtělo by se říci „navrátit“, ale nebylo by to přesné. Materiální a empirické variace jakožto konkrétní realizace systému byly v rámci strukturalismu chápány jako přinejmenším sekundární.

28

Diference je pouze věcí systému popisu, je věcí odlišených idejí, nikoliv „věcí, či „věci“ a „znaku“. 
a procesu atd. Vyjádřeno lakonicky: stejně jako je „věc-znak-věc-znak-věc“ je „sémiotikasémiotika-sémiotika-sémiotika-sémiotika“. Latourův obrat od idealismu Greimasovy sémiotiky je tak platný co do programu a prohlášení, ale v jistých aspektech stále zůstává v jejích jazykověcentrických osidlech: znakový proces je co do systému podř́zen dyadickému, kvazistrukturalistickému modelu bilaterálního znaku).

V následující části tohoto textu chceme ukázat, že obrat vstříc možné materiální sémiotice, která pojímá „věci“, jež „něco dělají“, je možný spíše obratem k jinému typu znakové teorie, $\mathrm{k}$ jinému typu pojetí znaku/relace, než je výše tematizovaná dyadická relace, kde diference je nakonec pouze věcí systému popisu a je věcí odlišených idejí, nikoliv věcí. Jde o pojetí znaku jako triadické ontologické relace, kde v povaze této relace je diference pochopená jako diference mezi tím, co je zastupováno (objektem), tím, jak je toto zastupováno něčím jiným (representamen), a tím, jaký efekt toto zastupování determinuje (interpretant). Takto pojatá sémiotická teorie přisuzuje $\mathrm{v}$ jádru samotné definice klíčový ohled na činnost reprezentovaných objektů, a nikoliv pouze na činnost systému, na který jsou tyto objekty a fortiori redukovány. Máme zde na mysli Peircovu sémeiotiku, kvazinutnou doktrínu, která analyzuje vznik a akci znaků, tedy sémiosis, kde znaková relace není brána jako jsoucno podř́zené systému jazyka, ale jako vztah na systém jazyka neredukovatelný. Znak, který je chápán jako autonomní modus relace, jenž je v jádru jakékoliv (i non-lidské) reprezentace.

\section{Sémeiotika: od logiky k obecné teorii znaku}

Stejně jako v předchozím pojednání se i zde omezme na aspekty sémeiotiky, které jsou podstatné pro argumentaci tohoto textu. Možná teorie významu a aktérství zde není především vázána na sémiologii (Švantner 2014; 2017). Demonstrujme to na základě rozdílného obsahu výrazů jako „relace/znak“, „diference“, ,inference“ a „,objekt”. V rámci sémiologie je „znaková relace“ v základě nemateriální jednotící figurou (abstraktní entitou, kterou je možno empiricky „,saturovat"), je bytostně dyadická ${ }^{29}$ a transcendentální (dedukovaná z imanentních vlastností systému jazyka). Latour tento model nechává poněkud v pozadí a akcentuje model sémiotický, prezentovaný jakožto komplementární (resp. symetrický) vztah ideového systému a jeho realizované materializace. Z hlediska (CP 2.228; CP 8.343) sémeiotiky je však znak uchopen jako triadická relace (i) objektu, (ii) toho, jak může být (objekt) zastupován něčím jiným, než je sám (skrze jistý typ reprezentace, tj. representamen), a (iii) jakým způsobem toto zastupování obecně umožňuje nějakou interpretaci (tj. interpretant, nikoliv interpret). Peircova perspektiva vychází z ohledů: ,i) ontologických (jako je ontologický status objektu, ${ }^{30}$ který je účasten znakového procesu); ii) logických (znak chápaný jako termín,

Případně - jako tetradického modelu znaku u Greimase - rozložitelná na sady dyadických vztahů. „Peircova perspektiva tak bere v ohled samotnou povahu zatupovaného objektu - a tedy toho, jak může takový objekt vůbec být: zda např. se jedná o ,myšlenku“, abstraktní entitu či nějakou ,,fyzickou věc" (CP 2.230); jakými možnými způsoby může být daný objekt reprezentován a jak tato reprezentace vymezuje možnosti interpretace dané reprezentace v rámci nějaké mysli (CP 2.242)““ (Švantner a Šedivcová 2019: 23). 
propozice a argument); iii) fenomenologických (faneroskopických): [kde] znak [je] chápaný jako pozorovatelná kvalita, existence a zákon či regularita“ (Švantner a Šedivcová 2019: 22).

V rámci sémiologického programu je diference uchopena jako klíčová věc pro definici samotného systému/struktury (ve kterém jsou realitou pouze rozdíly). V rámci samotné znakové relace je klíčová ze dvou důvodů: definuje povahu znaku jako dyadicky diferenční jednotky (označující není označované a vice versa) a určuje hodnotu znaku (obecně v rámci celého systému a na syntagmatických a paradigmatických osách). Tato dyadicko-diferenční relační logika stojí za celým sémiologickým i sémiotickým a do velké míry i Latourovým programem.

Peircem ovlivněná perspektiva je odlišná: diference sama je triadické povahy, a to nikoliv ve smyslu toho, že ke dvojici označované-označující „přidáme navíc“ objekt. Fundamentálně-ontologický rozdíl je zakotven v jádru samotné definice znaku/relace, a to $\mathrm{v}$ diferenci mezi objektem (materiální či nemateriální povahy) a něčím jiným, než je sám, tedy tím, co jej zastupuje. Znak je však bytím triadické relace: třetím elementem je zde efekt (interpretant), který tento vztah (zastupovaný objekt) vyvolává a který je (protože je efektem) povahou odlišný od povahy objektu (relačního prvku determinujícího) a representamenu (relačního prvku zprostředkovávajícího tuto determinaci, CP 1.292, 1.339, 1.346).

Pojetí znaku i jeho klasifikace je pak odvislé nikoliv od diference v rámci dané struktury, ale od hlediska relační povahy těchto elementů. Tato znaková relativita je fenomenologicky definována jako uchopující znakovou relaci co do její potenciality, realizovaného vztahu a regularity (CP 1.148-1.420). Např. objekt se může ve znakové relaci aktuálně či neaktuálně realizovat (CP 8.335), interpretant může mít podobu konkrétní inference nebo pouze vágního pocitu (CP 1.304). To, co sémiotika nazvala jako aktanční strukturou a Latour reinterpretuje ne-idealisticky jako sít', může z této perspektivy získat plastičtější (a tedy kýžený flat-onto$\log y$ ) rozměr.

Triadická povaha znaku je inferenční povahy (CP 5.213-5.263). Peirce chápe inferenci široce: je podle něj elementárním procesem, ve kterém se jakkoliv usuzuje $\mathrm{z}$ něčeho, co je reprezentováno (CP 5.462), a netýká se pouze tradičního pojetí usuzování závěrů z premis, ale $\mathrm{v}$ podstatě jakékoliv interpretativní aktivity. Peirce toto vysvětluje za pomocí tř́ obecných forem usuzování, jimiž jsou abdukce (hypotéza), indukce a dedukce. Kde hypotetické usuzování je spojeno s vágností, induktivní s pravděpodobností a deduktivní s regularitou (CP 1.545-1.567).

Zatímco tedy Latourova logika reference (,inskripce“) spočívá v materializovaném induktivismu (silné řetězce cirkulujících referencí spočívají v dostatečné iteraci), sémeiotická perspektiva chápe sémiosickou činnost aktérů (kterou se vztahují k nějakým věcem, což zde znamená k objektům znakové relace) spojenou s celou škálou inferenčních operací (hypotetických, induktivních i deduktivních). Sémeiotika tedy nabízí perspektivu, ve které znak není statickým - at' už binaristicky či inskriptivně - definovaným jsoucnem, ale činnou relací, jež skrze široce pochopený inferencialismus heterarchicky svazuje dohromady jak ontologické aspekty věcí samých, tak kognitivní mohutnost interpretačních mechanismů. 


\section{Závěr? Latour a Kohn o aktérství mezi strukturální sémantikou a sémeiotikou}

Jak tedy lze vést debatu o sémioticko-ontologických aspektech teorie aktér-sít' (dále ANT) mimo rámec Latourova obecného dělení na „sémiotiku diskurzu“ a „sémiotiku věcí / materiální sémiotiku“?

Můžeme si zde vypomoci návodnou interpretací sémeiotiky, jak ji prezentoval americký sémiotik John Deely (1942-2017), když vysvětluje právě povahu znaku jakožto autonomní ontologické relace. Pokud platí, že znak je něco, co zastupuje nějaký objekt (vzhledem k něčemu dalšímu), tj. znak je relační termín a objektem není nějaká věc o sobě, ale to, jak je věc prostřednictvím znaku reprezentována, je zájmem sémiotického bádání právě tato, Deelyho slovy, „objektivní realita“ (Deely 2009a; 2015; Deely 2010, s. 84-89). Zatímco v kvaziidealistickém sémiologickém aparátu nemá žádná taková realita objektu jakožto objektu znaku konceptuální místo, nebo je - jako i Latourem - převedena nakonec do dyadické relace „cirkulující reference znak-věc“, v sémeiotickém prizmatu je otázka reprezentace věci ve zkušenosti výchozím bodem zkoumání. Sémeiotická fabrikace tak není analogická ani jednomu z Latourem v úvodu nastíněných piliřù.

Charakteristickým aspektem této specificky uchopené „objektivní reality“ je znak, pochopený jako ontologická relace (relatio secundum esse), která je jako taková jednak sice superordinovaná, ale zároveň indiferentní vůči ontologickému statutu svých termínů: tj. vztah mezi elementy takto uchopené struktury znaku může být bud' reálný, nebo pouze myšlený, a přesto se jedná stále o jednu a tutéž relaci. Bez koncepce objektu znaku by - pro Peirce, a zejména pro Deelyho - prostě nebyly možné vůbec znaky, a tedy ani možný žádný jazyk ani nakonec latourovský model inskripce a artikulace...

V Deelyho perspektivě, která je vedle barokní scholastiky a Peirce inspirovaná jeho učitelem, biologem T. A. Sebeokem, tak žádný způsob komunikace znaky - a tedy ani lidský jazyk - není odlučitelný od prostředí, ve kterém probíhá. Klíčovým rozdílem je - jak oproti sémiologii, tak oproti strukturální sémantice - zde konceptuální uchopení Uexküllova pojmu prostředí (Umwelt). Deely interpretuje prostředí jako právě utvořené výše definovanou znakovou („objektivní“ či „objektovou“) realitou (Deely 2009a; srov. Deely 2010, s. 17). Tedy to, jakými způsoby jsou věci reprezentovány znaky jako objekty v pozornosti kognitivního aparátu organismu je to, co definuje prostředí, jakožto bytostnou součást procesu vznikání a akce znaků - sémiosis (Deely 2010, s. 53).

Odtud by bylo možné vést subtilnější vypracování klíčového pojmu Latourovy koncepce, kterou má být i právě základní ontologická vlastnost univerza, kterou je „artikulace“. $\mathrm{S}$ pojmem znaku se totiž zde nezachází jako s dyadickou nominalistickou relací spojenou per se s (s lidským) diskurzem: parafrázujeme-li Latoura, texty se nepíší samy, ale vznikají (v Deelyho smyslu) v „objektivním“ prostředí sémiosis.

Aspekty tohoto prizmatu, které vedly $\mathrm{k}$ přátelskému střetu, lze nalézt právě $\mathrm{v}$ pozicích zmíněné debaty. Kohn se ve svém pojednání pokouší zapojit právě aspekty znakového procesu, které jdou za Greimasovu strukturální sémantiku. ${ }^{31}$ Vkladem Kohnovy práce (vedle obdivuhodného etnografického výzkumu) je právě zapojení některých součástí

31 Dodejme, že by bylo námětem na samostatnou studii, jakým způsobem to činí a nakolik jsou jeho interpretace poplatné původním textům. 
z postpeircovské ontologie. Nepřekvapivě se jedná především o druhou, široce popularizovanou triádu Peircovy raně-pozdní znakové klasifikace popisující znakovou relaci uchopenou z pozice vztahu representamenu a zastupovaného objektu, tj. znak-ikon, znak-index a znak-symbol, přičemž v zásadě jde o vztah zastupování na základě kvality, soumeznosti a zákona. ${ }^{32}$ Kohnův kvazisémeiotický projekt lze chápat právě jako snahu učinit artikulační sít', ve které aktéŕi jednají „plastičtěji“. Pomůžeme-li si opět Deelym, tak „plastičtěji“ zde znamená to, že znak uchopený jako ontologická relace může determinovat rozličné typy jednání (interpretantů) lidských i non-lidských aktérů jak: (i) ikonicky (či obecně „mimeticky“), kdy se aktérství artikuluje podle znaku-ikonu, jenž je charakteristický tím, že je znakem sdílejícím se svým objektem jisté kvality; (ii) na základě soumeznosti a kauzality jako v př́padě indexikálních znaků; (iii) nebo na základě schopnosti organismu formovat tř́́du intenzionálních konceptů (tj. jednat „symbolicky“ [srov. Sebeok 1975b, s. 137]). Kohnovu snahu lze tak vidět právě jako pokus jít „za“ dyadickou logiku strukturalistických ontologií, a to nikoliv pouze ve smyslu přiznání aktérství non-lidskému, ale prostřednictvím komplexní změny pohledu spočívající v subtilnějším uchopení znakové relace. Znak v Kohnově pojetí je totiž chápán také jako aktér, který něco dělá. Pro Kohna je (Deaconův) Peirce jak branou k vpuštění pojetí naturalizované, živoucí sémiosis,$^{33}$ tak cestou $\mathrm{k}$ jinému promyšlení povahy vztahu jako takového a tedy i klíčového termínu artikulace, právě mimo limitující, dyadicky-diferenční perspektivu.

Jak Latour (2014) uvádí, když se vyjadřuje ke Kohnově textu, jeho znalost amerického „kryptického fillozofa“ (Peirce) je zprostředkována právě Kohnovou knihou, která, jeho slovy, co do stylu a konstrukce dělá, co ř́ká. Dostává se „za člověka“ a „Za jazyk“, avšak a to je podle Latoura klíčový bod jeho kritiky - nedostává se „za význam“. Latourovi se nezdá Kohnovo zavedení sémiosis jakožto „univerzálního spojovatele“ (universal connector) všech pojednávaných entit. Sémiosis je podle něj uchopena jako konceptuální nástroj, který má „vymazat“" veškeré uměle vytvořené distinkce (jazyka a světa apod.) a (v ontologickém smyslu, kdy si Latour půjčuje Deleuzeův slovník) jako to, co „ohýbá svět jedním směrem nebo směřuje pozornost $\mathrm{k}$ některému $\mathrm{z}$ těchto ohybů (podobně jako francouzské slovo sens)“ (Latour 2014: 2).

Ačkoliv se Latourovi nezdá zapojení „univerzálního spojovatele“, sám nakonec takového postuluje (jde o výše zmíněnou ,artikulaci“, „inskripci“ a „sémiotickou konstituci entit v rámci ANT“). Podstatnějši věcí je zde „ohnutî“" samotného termínu „sémiosis“"34, která, jak jsme uvedli výše, může mít mnohem techničtější smysl, než je vágní francouzské sens.

32 Dodejme, že Peircův termín „symbol“ se nepřekrývá se Saussurovou a Jakobsonovou interpretací (srov. Švantner 2017).

33 Za celým projektem stojí jednoduchá idea, prezentovaná jako základní motiv knihy T. Deacona (1997), kterou lze nalézt i v dalších pracích biosémiotiků, viz např. Deely (2009 ad.): zatímco lidští aktéři používají jazyk, a tedy specifickou/druhovou (species) formu komunikace (tedy sémiosis, tedy antroposémiosis), jiné druhy, jiní aktéři sice nepoužívají jazyk, ale použivají ke komunikaci znaky (nikoliv znaky ve smyslu Greimase, podřizené jednoduché formální logice implikace a disjunkce). Ergo i komunikace (a „artikulace“ a tedy sémiosis) non-lidských druhů probíhá ve znacích.

34 Jak Latourem, tak Kohnem. 
Máme zde na mysli obsah výrazu sémiosis denotující proces, ve kterém se nějaký interpretant (efekt vyvolaný znakovou relací) stává objektem pro další znak; případně pochopení sémiosis jako procesu toho, kdy se něco (znak) ocitá v pozornosti organismu (nebo stroje), a to opět $\mathrm{v}$ rámci různých modalit (vágnosti, relace, regularity).

Sémeiotika tak nabízí širší nástroje pro analýzu habitualizace univerza než Greimasova diskurzivněcentrická sémiotika, protože v ideji znakové triadické relace spojuje habitualizaci (řetězení interpretantů) jak lidských, tak non-lidských aktérů a nechává prostor pro analýzu jejich kognitivních funkcí, chování a inferování. Znak je směsí různých realit a sémiosis jako taková je jak naturalizovaná, tak lidská i non-lidská. Nikoliv tím, že pouze spojuje, ale tím, že vytváří rozdíly v reprezentaci a interpretaci: jako je lidská sémiosis nesená jazykem a specifickým prostředím jiná, než je napřr. pro roztoče. Odtud plyne konceptuální výhoda užití tohoto přístupu v Kohnově práci, a není tedy pouze „,výhybkou směrem od mluvících lidí“ (Latour 2014: 2): nestojí v kontrapozici k Latourově pojetí ANT pouze politicky, ale především ontologicky v tom smyslu, že rozšiřuje její konceptuálně-analytické možnosti.

Kohnův Peirce je Latourem viděn jako někdo, kdo umožňuje silná ontologická tvrzení, avšak ,př́liš rychle je stabilizuje do automorfismů“ (Latour 2014: 4). Což je snad přesné v př́ípadě Kohnovy (Deaconovy) intepretace Peirce, avšak je př́liš zjednodušující, co se samotného Peirce týče, který, pokud to lze takto říci, nechtěl skrze sémeiotiku postulovat jednoduché konjugace prvků, jež generují komplexní struktury, ale spíše zkoumat ontologické základy jejich možných vztahů. Tato výtka (,příliš rychlé stabilizace automorfismů“) by tak platila spíše i pro Greimase a obecně strukturalismus, kde stabilizace struktur a jejich následná komparace a izomorfie platí za jeden ze základních nástrojů strukturální analýzy (Descombes 1995). Latour (2014, s. 4) tak shledává - a nutno podotknut, že oprávněné nebezpečí v ,zabydlení“ takto „stabilizujícíc znakové teorie všude tam, kde je př́itomno nějaké jednání (a vyjednávání). Nicméně jeho výtka se týká opět spíše sémiologie a strukturalismu, kde je empirická varianta jednání odvislá od transcendentální diferenční struktury.

Takové pojetí je v rozporu s koncepty, které sémeiotika může přinést ANT. Sémeiotika není čistě apriorním popisem světa a aktér uchopený sémeioticky není reprezentovaný rejstříkem aktanční sítě podléhající kvazisémiologické binaristické logice, ale je uchopen v rámci komplexnosti triadické sémiosis. Tedy je uchopen jako jednající činitel: nikoliv ve vztahu ke znakům samým nebo ve vztahu k věcem samým, ale ve vztahu ke znakům, které zastupují objekty, které tyto znaky různými (,sít’ovými vztahy“) determinují. Tedy tím, co stojí za takto nazíranou reprezentací, není ani sociální konvence, ani přirozenost, ale schopnost znaku tyto dva pilíře transcendovat. Další výhodou sémeiotiky je to, že se neodvíjí z apriorního názoru a popisu (a předem stanovené struktury), ale z experimentálního abstraktního pozorování. Peircova znaková taxonomie a sémeiotika obecně není pokusem o vytvoření syntetické filozofie, která může být statickým modelem světa, ale pokusem o vytvoření genetického modelu interpretace možného vztahu mezi objektem, tím, jak je zastupován, a efektem, který toto zastupování vyvolává.

Cílem výše uvedených analýz tedy bylo ukázat jak na fundamentální rozdíly konceptualizace znaku, tak i koncepce objektu, který znak zastupuje, a právě to, jak se pojímání znaku i objektu napříč pojednávanými paradigmaty znakových teorií podstatně proměňuje. Ukázali jsme, že nejde pouze o slovníkové rozdíly, ale o rozdílné ontologické koncepce. Tato 
terminologická rozlišování a adaptace postpeircovského teoretického modelu znaku tak možná mohou vést ke kýženému překonání dělení sémiotiky věcí a sémiotiky diskurzu v rámci ANT.

\section{Dedikace}

Tento článek je výstupem projektu PRIMUS/17/HUM/24 Hybridní revoluční aktéři v globální politice podpořeného Univerzitou Karlovou.

\section{Literatura}

ABLALI, Driss. 2001. „Hjelmslev et Greimas: deux sémiotiques universelles différentes.“ Linx 44: $39-53$.

AKRICH, Madelaine a Bruno LATOUR. 2006. „Zusammenfassung einer zweckmäßigen Terminologie für die Semiotik menschlicher und nichtmenschlicher Konstellationen." Pp. 399-406 in Andrea BELLIGER (ed.). ANThology. Ein einführendes Handbuch zur Akteur-Netzwerk Theorie. Bielefeld: Transcript Verlag.

ARCHER, Margaret S. 1995. Realist Social Theory: The Morphogenetic Approach. Cambridge: Cambridge University Press.

BACHE, Carl. 2010. „Hjelmslev‘s Glossematics: A Source of Inspiration to Systemic Functional Linguistics?" Journal of Pragmatics 42(9): 2562-2578.

BAINS, Paul. 2006. The Primacy of Semiosis: An Ontology of Relations. Toronto, Buffalo, London: University of Toronto Press.

BEETZ, Johannes. 2013. Latour with Greimas Actor-Network Theory and Semiotics. Cit. 14. 5. 2020 (https://www.academia.edu/11233971/Latour_with_Greimas_-_Actor-Network_Theory_and_Semiotics).

BEETZ, Johannes. 2016. Materiality and Subject in Marxism, (Post-)Structuralism, and Material Semiotics. London: Palgrave Macmillan.

BOURDIEU, Pierre. 1998. Teorie jednání. Praha: Karolinum.

BRANDT, Per A. 2007. „On Consciousness and Semiosis.“ Cognitive Semiotics 1: 46-64.

BROŽ, Luděk a Tereza STÖCKELOVÁ. 2015. „Přísliby a úskalí symetrie: sociální vědy v zemi za zrcadlem." Cargo 1-2: 5-33.

CLARKE, Simon. 1981. The Foundations of Structuralism. Sussex: The Harvester Press.

DEACON, Terrence. 1997. The Symbolic Species. The Co-evolution of Language and the Brain. New York: W.W. Norton \& Company.

DEELY, John N. 2001. Four Ages of Understanding: The First Postmodern Survey of Philosophy from Ancient Times to the Turn of the Twenty-First Century. Toronto: Toronto University Press.

DEELY, John N. 2006. „On ,Semiotics“ as Naming the Doctrine of Signs.“ Semiotica 158(4): 75-139. DEELY, John N. 2009. Pure Objective Reality. New York: Mouton de Gruyter.

DEELY, John. N. 2010. Semiotic Animal: A Postmodern Definition of „Human Being“ Transcending Patriarchy and Feminism. South Bend: St. Augustine Press.

DESCOMBES, Vincent. 1995. Stejné a jiné. Praha: OIKOYMENH.

DORFMAN, Eugène. 1969. The Narreme in the Medieval Romance Epic: An Introduction to Narrative Structures. Toronto: University of Toronto Press.

DUCROT, Oswald a Tzvetan TODOROV. 1972. Dictionnaire encyclopédique des sciences du langage. Paris: Seuil. 
EAGLETON, Terry. 2010. Úvod do literárni teorie. Praha: Albatros.

ECO, Umberto. 1984. Semiotics and Philosophy of Language. London: MacMillan.

ENGLER, Rudolf. 2004. „The Making of the Cours de linguistique générale.“ Pp. 47-58 in Carol SANDERS (ed.). Cambridge Companion to Saussure. Cambridge: Cambridge University Press.

FILIPEC, Josef. 1969. „K francouzskému Greimasovu pokusu o strukturní sémantiku.“ Slovo a slovesnost 30(4): 423-428.

GAGARIN, Michael. 2002. Antiphon the Athenian. Austin: University of Texas Press.

GREIMAS, Julien A. 1966. Sémantique structuale. Paris: PUF.

GREIMAS, Julien A. 1971. „Narrative Grammar: Units and Levels.“ Modern Language Notes 86: 793-807.

GREIMAS, Julien A. a Joseph COURTÉS. 1982. Semiotics and Language: An Analytical Dictionary. Bloomington: Indiana University Press.

GREIMAS, Julien A. 1983. Structural Semantics: An Attempt at a Method. Lincoln \& London: University of Nebraska Press.

GREIMAS, Julien A. 1987. On Meaning. Selected Writings in Semiotic Theory. Minneapolis: University of Minnesota Press.

GVOŽDIAK, Vít. 2014a. Základy sémiotiky 1. Olomouc: Nakladatelství Univerzity Palackého.

GVOŽDIAK, Vít. 2014b. Základy sémiotiky 2. Olomouc: Nakladatelství Univerzity Palackého.

GVOŽDIAK, Vít. 2019. „Arbitrariness and Rationality.“ Sign System Studies (v tisku).

GREGORCZYK, Anna. 1989. „Reconstruction of Myth in the Semantics of A. J. Greimas.“ Pp. 49-67 in Jerzy KMITA a Krystyna ZAMIARA (eds.). Visions of Culture and the Models of Cultural Sciences. Amsterdam: Rodopi.

HERBERT, Louis. 2007. Dispositifs pour l'analyse des textes et des images. Limoges: Presses de l'Université de Limoges.

HANKE, Miroslav, Martina KASTNEROVÁ, Martin ŠVANTNER a Marie VĚTROVCOVÁ.

2015. Stopováni sémiotiky. Červený Kostelec: Pavel Mervart.

HARTMANN, John. 2010. „Review of Graham Harman, Prince of Networks: Bruno Latour and Metaphysics.“ Kinesis 36(2): 65-70.

HOSTAKER, Roar. 2005. „Latour - Semiotic and Science Studies.“ Science Studies 18(2): 5-25.

HJELMSLEV, Louis. 2016 (1943). O Základech teorie jazyka. Praha: Academia.

CHARVÁT, Martin. 2016. Gilles Deleuze. Asignifikantní sémiotika. Praha: Togga.

CHARVÁT, Martin a Michal KARLA. 2018. „Gilles Deleuze's Theory of Sign and Its Reflection of Peircean Semiotics.“Pp. 134-51 in Vít GVOŽDIAK a Martin ŠVANTNER (eds.). How to Make Our Signs Clear: C. S. Peirce and Semiotics. Leiden: Brill.

KELLY, John D. 2014. „Introduction: The Ontological Turn in French Philosophical Anthropology.“ Hau: Journal of Ethnographic Theory 4(1): 259-269.

KOBES, Tomáš. 2015. „Když se lidé mění ve lvy: Problém překladu.“ Teorie Vědy 3: 303-323.

KOHN, Eduardo. 2013. How Forests Think: Toward an Anthropology Beyond Human. Berkley, CA: University of California.

KONOPÁSEK, Zdeněk. 2015. „Symetrie je často stranická: rozhovor se Zdeňkem Konopáskem (Luděk Brož, Tereza Stöckelová).“ Cargo 1-2: 117-132.

LATOUR, Bruno a Madelaine AKRICH. 1992. „A Convenient Vocabulary for the Semiotics of Human and Nonhuman Assemblies." Pp. 259-264 in Wiebe E. BIJKER a John LAW (eds.). Shaping Technology/Building Society: Studies in Sociotechnical Change. Cambridge, MA: MIT Press.

LATOUR, Bruno a Steve WOOLGAR. 1979. Laboratory Life. The Contruction of Scientific Facts. Princeton, NJ: Princeton University Press.

LATOUR, Bruno. 1993. We Have Never Been Modern. Cambridge, MA: Harvard University Press.

LATOUR, Bruno. 1996. „On Actor-Network Theory: A Few Clarifications.“ Soziale Welt 47(4): 369-381. 
LATOUR, Bruno. 1996b. „On Interobjectivity.“ Mind, Culture, and Activity 3(4): 228-244.

LATOUR, Bruno. 1999. Pandora's Hope. Essays on the Reality of Science Studies. Cambridge, MA: Harvard University Press.

LATOUR, Bruno. 2005. Reassembling the Social: An Introduction to Actor-Network-Theory. Clarendon: Oxford University Press.

LATOUR, Bruno. 2008. „Poznání a vizualizace aneb jak myslet očima a rukama.“ Teorie vědy 30(2): 90.

LATOUR, Bruno a Courtney WEISS. 2009. „Where Constant Experiments Have Been Provided. A Conversation with Bruno Latour.“ Cit. 21. dubna 2020 (https://wittenbrink.net/lostandfound/ wp-content/uploads/2011/07/Arch-Literary-Journal-_-Bruno-Latour.pdf).

LATOUR, Bruno. 2014. „On selves, forms and forces.“ HAU: Journal of Ethnographic Theory 4(2): 261-266.

LATOUR, Bruno. 2014b. „How Better to Register the Agency of Things (Tanner One -semiotic).“ Cit. 21. dubna 2020 (http://www.bruno-latour.fr/sites/default/files/137-YALE-TANNER.pdf).

LAW, John. 2009. „Actor Network Theory and Material Semiotics.“ Pp. 141-158 in Bryan S. TURNER (ed.). The New Blackwell Companion to Social Theory. Oxford: Wiley-Blackwell.

LENOIR, Timothy. 1994. „Was That Last Turn a Right Turn? The Semiotic Turn and

A. J. Greimas.“ Configurations 2: 119-136.

LOTMAN, Jurij M. 1991. Universe of the Mind. A Semiotic Theory of Culture. Bloomington: Indiana University Press.

LOTMAN, Mihhail. 2003. „Peirce, Saussure and the Foundations of Semiotics.“ Sun Yat-sen Journal of Humanities 16: 77-78.

McGEE, Kyle. 2014. Bruno Latour: The Normativity of Networks. London: Routledge.

MEIER-OESER, Stephen. 1997. Die Spur des Zeichens. Das Zeichen und seine Funktion in der Philosophie de Mittlealters und frühen Neuzeit. Berlin: Walter de Gruyter.

MURPHY, James B. 1991. „Nature, Custom, and Stipulation in the Semiotic of John Poinsot.“ Semiotica 83(1/2): 33-68.

PAPILLOUD, Christian. 2018. „Bruno Latour and Relational Sociology.“ Pp. 183-197 in François DÉPELTAU (ed.). The Palgrave Handbook of Relational Sociology. Cham: Palgrave Macmillan.

PEIRCE, Charles S., Charles HARTSHORNE, Paul WEISS a Arthur W. BURKS. 1931-1958. Collected Papers of Charles Sanders Peirce. Cambridge, MA: Harvard University Press. (CP číslo svazku: paragraf)

PETTIT, Phillip. 1977. The Concept of Structuralism: A Critical Analysis. Berkley: University of California Press.

SALINAS, Francisco J. 2016. „Bruno Latour's Pragmatic Realism: An Ontological Inquiry.“ Global Discourse 6(1-2): 8-21.

SAUSSURE de, Ferdinand. 2007 (1916). Kurs obecné lingvistiky. Praha: Academia. (CLG)

SCHINKEL, William a Jacques TACQ. 2004. „The Saussurean Influence in Pierre Bourdieu's Relational Sociology.“ International Sociology 19(1): 51-70.

SCHLEIFER, Ronald. 1988. A. J. Greimas and the Nature of Meaning: Linguistics, Semiotics and Discourse Theory. London: Croom Helm.

SHORT, Thomas L. 2007. Peirce's Theory of Signs. New York: Cambridge University Press.

ŠVANTNER, Martin. 2014. „O jedné bouři v čajovém hrnku: Ch. S. Peirce, U. Eco a sémiotická metafyzika objektů.“ Filozofia 69(1): 63-76.

ŠVANTNER, Martin. 2017. „Nepochopená setkání: sémiotika a sociální věda o médiích.“ Sociálni studia 2: 99-122.

ŠVANTNER, Martin a Karolína ŠEDIVCOVÁ. 2019. „Číst v relacích: dekonstrukce, sémiologie, sémeiotika a ironie dějin teorie znaku.“ Pp. 19-51 in Martin ŠVANTNER, Michal KARL'A a Karolína ŠEDIVCOVÁ (eds.). Sémiotické marginálie: Mezi epistemologií, estetikou a politikou. Praha: Togga. 


\section{Autor}

Martin Švantner (*1982) vystudoval politologii, filozofii a sémiotiku a antropologii. Jeho hlavním zájmem je obecná a kognitivní sémiotika, dějiny sémiotiky, teorie rétoriky, sémiotika hudby, současná sociální teorie a filozofie a dílo Ch. S. Peirce.

Kontakt: martin.svantner@fhs.cuni.cz 